\title{
Sumaq Kawsay: the birth of a notion?
}

\section{Sumaq Kawasay: o nascimento de uma noção?}

\author{
Francisco Salgado ${ }^{1}$
}

\begin{abstract}
The objective of this paper is to explore critically a recent development and management approach from our own locus of enunciation. Sumaq Kawsay, a Quechua expression commonly translated as "well-living" - in opposition to "well-being"- , has been chosen as the leitmotiv by Ecuadorian and Bolivian Constitutions in the past two years.
\end{abstract}

Keywords: Sumaq Kawsay, development, citizenship, social systems delineation, social management, Ecuador.

\section{Resumo}

O objetivo deste artigo é explorar criticamente, a partir do locus particular da enunciação, uma abordagem de gerenciamento e desenvolvimento recente. Sumaq Kawsay, uma expressão quíchua, normalmente traduzida como "viver bem" em oposição a "bem estar", foi escolhida como leitmotiv pelas Constituições do Equador e da Bolívia nos últimos dois anos.

Palavras-chave: Sumaq Kawsay, desenvolvimento, cidadania, delimitação dos sistemas sociais, gestão social, Ecuador.

\section{Introduction}

May the principle of Sumaq Kawsay be used to discuss about new development and organizational thinking from a Latin American perspective? The objective of this paper is to explore critically a recent development and management approach from our own locus of enunciation. Sumaq Kawsay, a Quechua expression commonly translated as "well-living" - in opposition to "well-being"-, has been chosen as the leitmotiv by Ecuadorian and Bolivian Constitutions in the past two years. The academic and social groups in which the term was first used, aim to propose a new development model based in Andean cultural roots. This initiative is considered as a novel viable alternative for organizing communities, institutions and the nation as a whole. However, since it is recent to academic discussion, it is still in a very early stage, as a motivating idea in the path of constructing a development model.

Therefore, the Sumaq Kawsay notion requires more critical thinking in order to constitute itself as a theoretical perspective worth exploring. It can be considered to be a utopian view; and, as utopia, it has the anticipation capacity of foreseeing new possibilities: development paradigms that do not exist yet, but are nevertheless viable. As utopia, Sumaq Kawsay may be considered as resistance to current mainstream thinking and the proposal of a changing praxis of new possible development and organizational thinking. It is certainly risky to explore the birth of a notion that is occurring right now in the Andean area, but it is what is needed in order to learn from social experience in our present world, which is more diverse and rich than what that mainstream assumes.

A life worth living comes in very diverse shapes and flavors; however, predominant models have ignored this diversity and have fragmented contemporary world in two opposite and divided worlds: that of the modern occidental world and that of the excluded cultures. To recover what has been ignored is a social justice aim. Deconstruction of Sumaq Kawsay and the original economy - oıкко-voнos - discourses, is the method that

Paper received in April 2010 and accepted for publication in June 2010.

${ }^{1}$ Universidad Andina Simón Bolívar, Sede Ecuador - Universidad del Azuay. Address: Av. 24 de mayo 777, Cuenca - Ecuador; E-mail: fsalgado@uasb.edu.ec. 
will be used to assemble a ethic and aesthetic approach to development, from a Latin American and Andean perspective.

Although Sumaq Kawsay originated as a cultural notion from Andean civil society, a notion that was elucidated by anthropology and latterly displaced to academic and political discussions; it seems that, in actual practice, civil society has been ignored by the very same groups that use its cultural discourse in their public policies. In Andean countries, the centrality of civil society that the Sumaq Kawsay principle supports, has been replaced by a strong state concept, which justifies every political action beneath its actual social impact. The power of the state is not only constraining the freedom of the market - the place where human beings share the fruits of their labor, according to Plato - but it is strangulating civil society participation.

May Sumaq Kawsay be really a new development local model that allows a new order based on increased and empowered social participation that would lead actions both from the state and markets?. The paper would describe this issue from an anthropological point of view and analyze it from a sociological and organizational perspective, using the Brazilian authors Alberto Guerreiro-Ramos' theory of social systems delineation and Fernando Tenório's deliberative citizenship.

\section{Sumaq Kawsay as a world view of the Andean culture}

The Quechua are the largest group of American Indians in the world today. They live in both the Andes Mountains and the tropical rain forests of the Amazon basin mainly in Bolivia, Ecuador and Peru; although the term Quechua is essentially used to refer to the language they speak. Quechua and Spanish are the most common languages spoken in South America. And while many native languages have been declared dead in modern times, the language of the Quechua has flourished.

A language with many dialects, Quechua is spoken by some 10 million people today (GIBSON, 2005). The Quechua belong to an ancient culture that has much to teach the rest of the world. The Quechua people hold on to traditions that provide a sense of unity and cultural heritage. While they live in poor conditions, they have survived for as long as a thousand years, based on a cultural praxis of solidarity and cooperation known as Andean reciprocity.

Andean reciprocity has been viewed in terms of differing degrees of social integration. Institutional forms of work exchange such as minka, cambia-manos, faena and ayni establish and maintain social boundaries in varying degrees of inclusiveness within Andean communities. Perceptions of nearness and distance, inclusion and exclusion are important dimensions in this understanding (SKAR, 1995). Reciprocity has focused upon work as the essential ingredient to such exchanges, besides food and drink, but with absence of money.

In the Andean world of peasant agriculture, wisdom is love, nurturance, symbiosis, conversation, reciprocity, and dance (ISHIZAWA; GRILLO, 2002). That wisdom may be comprehended by the Quechua expression Sumaq Kawsay, commonly translated as "well-living" - in opposition to "well-being"- . The notion of Sumaq Kawsay has been lately the subject of academic debate in Latin America, particularly in Ecuador, since it has been chosen as the leitmotiv by Ecuadorian and Bolivian2 Constitutions in the past two years.

The Ecuadorian Constitution in particular introduces, for the first time, the idea of nature as a subject entitled to rights, in the same way as human beings. The academic and social groups in which the term was first used, aim to propose a new development model based in Andean cultural roots, built on respect, equality among all, solidarity, harmony and equity (ALBÓ, 2009), (CHIROQUE; MUTUBERRÍA, 2009), (KESSEL, 2006) and (MORRISEY, 2009). But what does Sumaq Kawsay actually mean as a symbol in the indigenous Andean Quechua cultural context?

A method that can be used to understand the cultural meaning of Sumaq Kawsay is to deconstruct its semantics; that its, go deeply to its original roots, dismounting and reassembling its elements, in order to construct new discourses and notions (FELDMAN et al, 2004). According to Carreño (2006), Sumaq Kawsay has an

\footnotetext{
${ }^{2}$ Suma Qamaña is the Aymara term used in Bolivia, but its cultural context and semantics corresponds to the notion introduced in this paper.
} 
aesthetic feature, since its first term - Sumaq - means beauty, tenderness. Therefore, in this cultural milieu, Sumaq Kawsay is a notion that expresses a tender and beautiful living. According to Albó (2009), Suma Qamaña, the Aymara equivalent of Sumaq Kawsay, means well-living together and supporting each other.

Another interesting approach is to analyze some ethnographic Andean studies that reveal its people's emic perspective (HARRIS, 1976). Most of these studies reach the conclusion that, according to the Andean culture's world view, the final objective of human activity is not power or money accumulation, but the nurturing of a tender, harmonious and vigorous life - a Sumaq Kawsay - (KESSEL, 2006), both for humanity and Mother Earth: the Pachamama.

The fundamental value in the Andean culture is life, and the essence of life is the Pachamama. Since everyone and everything come from the Pachamama, the main dedication is to nurture life in all its forms. Therefore, a Sumaq Kawsay is tenderly cultivated, it is certainly socially constructed (MALLON, 2007). Furthermore, if one takes into account the paramount use of the progressive tense in the Quechua language, a Sumaq Kawsay is being raised gradually, in a continuing and enduring fashion.

The linguistic and anthropological analysis above introduce the main purpose of this paper: comprehending the meaning of Sumaq Kawsay as a new development and cooperation notion. In order to understand this innovative Andean conception, a comparative approach may be used, following the sociological and organizational propositions that were suggested by Alberto Guerreiro-Ramos in the third quarter of the 20th century, but has largely remained unknown outside his home country (SALGADO, 2008): sociological reduction and the theory of social systems delineation, among other considerations about human models, public administration and Latin America development. Sumaq Kawsay will also be contrasted with the deliberative citizenship notion proposed by Fernando Tenório, a concept that is located in-between society and state.

\section{Sumaq Kawsay: a praxis of sociological reduction}

The Brazilian author Alberto Guerreiro-Ramos proposes in his A redução sociológica (2001), that a given community, in order to understand its own reality, needs to practice sociological reduction, taking advantage of the experience from abroad, but focusing in the realization of its own historical project. Doing so, he warns against the transposition of foreign problems to the reality at hand. Sociological reduction has a triple meaning: a) critical assimilation of foreign sociological science; b) resistance to the massification of organizational conduct and pressures; and, c) furthering sociological science from its current models (GUERREIRO RAMOS, 1981).

Predominant theories had proposed deterministic models, leaving aside particular values and emphasizing as universal the characteristics of the Western world. Guerreiro-Ramos rejected these ideas, and argued that countries at the periphery should not follow these examples in a naïve and passive way. He advocated the development of Latin American social theories by "critical assimilation of foreign sociological patrimony" (VENTRISS; CANDELL, 2005). Reduction in this sense is understood as a critical assimilation, a process of distilling the international social science literature so as to reduce it to the part that is relevant, and therefore useful, to Latin America. Thus, foreign literature should be subsidiary to Latin American reality.

Sociological reduction is a methodological approach that aims to apprehend the fundamental structures of sociological concepts, phenomena or data, by reducing or distilling their referential assumptions, of historic characteristics, from the facts or objects of the studied reality (GUERREIRO RAMOS, 2001). The Brazilian author notices the conflict between organizational thinking from a universal perspective and administrative theories from a particular perspective, and advocates administrative particularism as the center of his sociological reduction proposal, arguing the necessity to adapt universal concepts to each particular case (CANDLER, 2002). That is the case for Sumaq Kawsay, a development model conceived as an Andean particularism that could be adapted to other territories in Latin America.

Development and public administration are deeply related to society, and critically depend on a local, regional or national context. Therefore, policy research is crucial to context understanding, and Latin American must adapt development lessons from other nations, particularly the developed world experiences. On one hand, Guerreiro-Ramos saw the center-periphery difference as fundamental, and strongly criticized the mechanical 
adoption of development experiences from the central countries. On the other hand, he pointed out the importance of considering Brazilian particular condition even among peripheral countries themselves (CANDLER, 2002).

Therefore, a country development must be considered as a collective project, with its own historic uniqueness, in which that country can be in control of its own reality and thus be able to define its future by itself. This idea is similar to that of Paulo Freire (2002), who stated that "our hands must rise to work together, not to plead". This line of thought clearly relates to the proposition of Sumaq Kawsay as a unique notion that may help Latin Americans to define our own development model and hence construct our future by ourselves.

\section{Sumaq Kawsay and a new model of human being}

Guerreiro-Ramos suggests in his Modelos de homem e teoria administrativa (1972) to revisit administrative theory trajectory by focusing on three models of human being: operational man, reactive man, and parenthetical man. Taylor's administrative theory considered a human being as an operational man, nothing but a resource that should be maximized in terms of a measuring product. Operational man is a passive individual that must be programmed to maximize production; a calculating character moved my material rewards, isolated and independent from other people.

Later on, "humanists" pretended to improve organizational theory by proposing and alternative human being, with a more sophisticated vision of the nature of human motivation, conceiving organizations as open systems, and taking into account people's behavior, values, and feelings along the production process. This kind of human being, according to Guerreiro-Ramos, may be named as a reactive man, an individual that reacts, that behaves according to stimuli that are functional to the organization, a person that adjusts him or herself to the work setting, giving up his or her personal realization.

In order to liberate the operational or reactive man, that lives comfortably imprisoned in his or her immediate surroundings, Guerreiro-Ramos suggests a parenthetical man, a person that is "suspended", an individual that is "between parenthesis", with critical consciousness of his daily reality. This critical awareness allows him or her to parenthesize mainstream believes or imposed rules, with the purpose of assessing them critically, and consequently realizing his or her freedom. Furthermore, the parenthetical man is committed ethically with social life, departing from frivolous relativism. In this sense, "a parenthetical attitude is defined as an individual psychological capability to separate himself from internal or external circumstances. Parenthetical men prosper when [...] social naivety comes to an end" (GUERREIRO RAMOS, 1972). Contesting the organizational man, restricted by his submission to the market, Guerreiro-Ramos advocates the parenthetical man with true social participation. "That is why today is not enough to administrate organizations, it is necessary to administrate the whole society" (GUERREIRO-RAMOS, 1972).

Parenthetical man would be the ideal type that Sumaq Kawsay sustains. Parenthetical man challenges the model of society and human beings submitted to the market and seeks solidarity in living together with other people and other species of the Pachamama.

\section{Sumaq Kawsay and the theory of social systems delineation}

The basic aim proposed by Alberto Guerreiro-Ramos is to constitute various scenarios, various enclaves in a society, in which a human being may realize him or herself. Market is but another enclave, it is not the hegemonic center anymore. In this way, a new setting of multidimensional characteristics appears, with ample possibilities of personal realization and social achievement. The notion of social delimitation implies that: a) a society is comprised of multiple domains, in which individuals associate for different activities; and b) a social government that formulates and implements policies that allow resource distribution, and the interaction between these various domains or social enclaves. The concept of organizational delimitation, confines formal, economizing organizations to a restricted enclave in the overall social fabric, allowing the cultivation of substantive rationality.

The notion of social delimitation is compatible to the Sumaq Kawsay world view, that celebrates the community of the heterogeneous in a permanent symbiosis where there is no center or hegemony. Therefore, in 
this symbolic cosmology, we may argue that both the state and the market are at the same level as other social spheres: no one is superior neither excluded. In the Andean case, the classificatory principle of dualism plays a key role by emphasizing reciprocity and thereby conveying the idea of an integrated cosmos (OSSIO, 1997). According to Ishizawa and Grillo (2002):

The Andean world, as a living and vivifying world, is an extremely diverse world of biological species, ecosystems, climates, geology, geography, and so on. It is a world happening at every moment and continuously, a world in which harmony is not given but is nurtured at each moment with the diligent participation of all of us who are this world. This is a communal world, a world of protection that does not exclude anyone. Each person (whether man, tree, or stone) is as important as any other in the daily nurturance of harmony.

Guerreiro-Ramos critiques instrumental reason and its influence in predominant social and organizational theories. Challenging this kind of reason that seeks utilitarian calculation, that submits itself to the market, he proposes a return to the program that Weber left unfulfilled: the rescue of substantive reason (WEBER, 1999 and 2004). Other authors have criticized modern reason, seen as instrumental, functional; such as Adorno with Horkheimer (1998), Habermas 1990, 2001) and Horkheimer (2002, 2004), to whom Guerreiro-Ramos refers in his "A nova ciência das organizações" (1981), book that is briefly analyzed in the following paragraphs.

\section{Sumaq Kawsay as global ecology}

The critique to instrumental reason, which is market-centered, proposes substantive reason, focused in human realization. These are opposite elements; therefore, current organizations are not the appropriate scenario for auto-realization, since they pretend total inclusion of people in their own limits, in the economy. Market is the force that shapes society as a whole. Human nature is understood inside the market; man is understood according to his (un)employment; communication is instrumental for profit maximization, it is seen as cognitive policy that dominates and misleads.

As he has stated in his previous works, Guerreiro presents the case against the school of human relations and organizational behavior. He argues that these theories are still instrumental, since they pretend to absorb people's lives, by assimilating their space wholly into the organization. In this instrumental vision, a human being is seen as an organizational individual that cannot be understood outside the organization, and does not have space for his own realization. Efficient employees are tailored according to imposed rules that define their behavior. By misplacing concepts, an individual psychological notion such as behavior, is translated to the organizational field, organizational behavior, with the instrumental purpose to increment the productivity of the system.

Even though the misplacement of concepts arise this kind of improper notions, Guerreiro-Ramos distinguishes it from the powerful potential of the displacement of concepts. The use of a certain concept in a different setting, may be promising for new theory construction; as Gareth Morgan does in his "Imágenes de la organización" (1991), in which he uses metaphors in order to understand how organizations function.

Contesting instrumental reason, which is market-centered and productivity-oriented, a different model of substantive reason is possible, a model that satisfies the necessity of human self realization in multiple social contexts. This model may be labeled as Sumaq Kawsay, or alongside Boeira (2002), as Global Ecology. It is certainly a new perspective that goes over the predominant one-dimensional vision, and is what we study in the following section, introducing the fundamentals of a new organizational theory.

\section{New organizational theory}

Guerreiro-Ramos indicates that current predominant organizational theory is a naïve one, since it is determined by instrumental reason, inherent to western social science. This naivety has permitted that instrumental reason achieves its practical purposes. These processes have been one-dimensional and have unfavorably changed social life; arising the necessity to question predominant administrative ethics (COOPER, 2004). Multidimensional formulation, as suggested by Guerreiro-Ramos, allows the search for new and diverse organizational forms that try to conjugate both human realization objectives, and optimal resource provision for 
goods and services production. Multidimensional formulation considers both paid and unpaid activities, formal and informal settings, as well.

In order to fundament his multidimensional view, Guerreiro-Ramos defines the predominant organizational

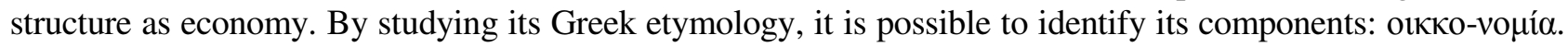
This linguistic construction is interesting: оєкко-vоцía is normally understood as administration. It is important to remember that vouí $\alpha$ originally meant "to nurture", to feed and take care of a child or a plant while it is growing. The term was used in the context of love and caring provided by mothers to their children. Here is where the relationship to the notion of Sumaq Kawsay clearly arises, since Sumaq Kawsay consists in knowing how to nurture and how to let oneself be nurtured in this living and vivifying world, the Pachamama, which must be loved and healed unreservedly. Therefore, the original Greek meaning of administration is far from the current mainstream, and etymologically relates to the Andean culture meaning of the loving care for the common good. This connotation corresponds fully with the original sense of the Latin word administrāre which, in its original sense, means service to other people.

Using the Greek root vouía, new words that fundament the comprehension of new forms of organization may

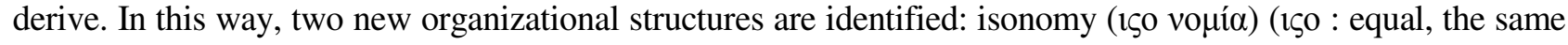
all through or in every part), and phenonomy ( $\varphi \varepsilon v 0$ vouía) ( $\varphi \varepsilon v 0$ : to show, to discover what is hidden, to create).

This multidimensional conception, allows to think of a diversity of organizational structures, from those organizational environments subjected to heavy regulation (economies) to those in which there are no rules at all (anomies). The dimensional borders of these structures are just referential, since they move across a continuum, where it is possible to find a great number of organizational forms between its opposite points. These borders are delineating categories of the individual/community organizational dimensions.

One of these possible scenarios is the isonomy organizational type, in which each and every member are equal, with the same rights and duties for everyone. This homogeneous structure promotes self realization and gratification, working in an environment in which activities correspond to vocations rather than jobs. What is more, decision-making is consensual, such as in community organizations, cooperatives, third-sector organizations, and others.

Another organizational representation is the phenonomy kind, which corresponds to rather stable social systems, with few individuals that share similar goals or objectives. Similarly as described above, phenonomies promote self realization and gratification, and the working environment corresponds to vocations. Scientific communities, research groups, artist communes, ecological groups, and others, can be mentioned as examples of phenonomies.

Sustainability is the key orientation of the notion of Sumaq Kawsay. Therefore, it may be nourished in different settings, according to the particular requisites of each one on a particular basis. The Quechua conception has its similar in what Guerreiro-Ramos denominates as the principle of adequate resources allocation. The principle of adequate resources allocation (or diversity of requisites principle) states that a variety of social systems may select their own arrange of requisites, so that each of their members may access to conditions of personal realization and needs satisfaction. From a variety of dimensions and arrangements, each social system may allocate the adequate resources that respond to their circumstances; and from there design their system delineation appropriately.

Five are the dimensions that may be combined for this system delineation: technology, size, cognitive system, time distribution, and space arrangement. Table 1 bellow shows how the five dimensions assemble into three organizational structures: economy, isonomy and phenonomy. 
Table 1: Principle of adequate resources allocation (or diversity of requisites)

\begin{tabular}{|c|c|c|c|c|c|}
\hline & Technology & Size & Cognitive System & Space & Time \\
\hline $\begin{array}{c}\text { Economy } \\
\text { (bureaucracy) }\end{array}$ & $\begin{array}{c}\text { High degree of } \\
\text { organization }\end{array}$ & Big-medium & Functional & $\begin{array}{c}\text { Society-edged } \\
\text { (centrifugal) }\end{array}$ & $\begin{array}{c}\text { Serial } \\
\text { (Kronos) }\end{array}$ \\
\hline $\begin{array}{l}\text { Isonomy } \\
\text { (equality) }\end{array}$ & $\begin{array}{l}\text { Human } \\
\text { realization- } \\
\text { oriented }\end{array}$ & $\begin{array}{c}\text { Self } \\
\text { Restrained } \\
\text { (With a } \\
\text { minimum and a } \\
\text { maximum) }\end{array}$ & Political & $\begin{array}{c}\text { Society- } \\
\text { centered } \\
\text { (centripetal) }\end{array}$ & Convivial \\
\hline $\begin{array}{c}\text { Phenonomy } \\
\text { (creativity) }\end{array}$ & $\begin{array}{l}\text { Innovation- } \\
\text { oriented }\end{array}$ & Small & Personal & $\begin{array}{l}\text { Society- } \\
\text { centered }\end{array}$ & $\begin{array}{c}\text { Leap (Kairós) } \\
\text { opportunity }\end{array}$ \\
\hline
\end{tabular}

Illustration based in (GUERREIRO RAMOS, 1981)

The principle of adequate resource allocation (or diversity of requisites principle) is summarized in the previous Table. This principle is the foundation of what Guerreiro-Ramos considers as a new paradigm for organizations: the para-economic paradigm. One of the paradigm aims is the adequate allocation of resources, according to each environmental particular reality. In this way, many organizational forms may not only coexist, but constitute a desired strength that enriches a society.

Para-economy postulates a society diversified enough to allow its members to deal with substantive issues of life according to their pertinent intrinsic criteria, and in specific settings where they belong. From the para-economic viewpoint, not only the economies which constitute the market enclave, but other substantive enclaves and the variety of their mixed forms are to be considered agencies for optimal allocation of resources and manpower. (GUERREIRO RAMOS, 1981)

The Sumaq Kawsay sustains a para-economy model that challenges the predominant model of society and the economy. It compels us to rethink development in a way that takes into account the perspective of those that have always been excluded from political decisions and who have suffered the consequences of a top-down approach. According to the para-economy model, market must be regulated in such a way that it cannot affect negatively isonomic and phenonomic enclaves, such as mutual systems, cooperatives, factories owned and managed by their workers, communal systems, and others. Self-sustained organizations are complementary to the current established economies, and their inter-relation strengths each other. Finally, it should be noticed that adequate resources allocation allows sustainability of ecosystems, the nurturance of both human beings and the Pachamama.

\section{Beyond social systems delimitation and into Sumaq Kawsay}

Sumaq Kawsay is totally founded in social participation, in living together with solidarity and tenderness for each other. This section aims to critically examine social systems delimitation theory, in order to progress on Guerreiro-Ramos' unconcluded work. The improvement refers to consider public policy more effectively, by using Habermas' communicative action, as proposed by Tenório, synthesizing human self-realization, intersubjective communication, and citizenship construction, in contemporary organizational theory.

It is possible to argue that Guerreiro-Ramos did not developed sufficiently the concern for public policy and inter-subjective relationship in his theory, concurring with Ventris and Candell suggestions (2005): a) Guerreiro-Ramos understated the role of the state and politics in his theoretical scheme (public policy concern); and b) He hardly addressed how an individual contains instrumental rationality in her/his relationships with other individuals as she/he goes from one enclave to another (inter-subjective relationship).

A probable explanation for this situation is that Guerreiro-Ramos was at the initial phase of formulation of his new science of organizations, and he was engaged in further elaboration on his death. Furthermore, he explicitly stated in A nova ciência, that there is more research to be done in order to construct a new social theory. In some way, he lacked the time to propose the social praxis that he aspired. 
The conceptual research lines that are discussed below are based on Fernando G. Tenório's intellectual trajectory, as described in his work "Teorías organizacionales bajo el orden y el progreso, o cuando los vivos son gobernados por los muertos" (2006). In order to approach the concern for inter-subjective relationship, communicative action is proposed; to consider public policy concern, the concept of deliberating citizenship is suggested.

\section{Theory of communicative action and Sumaq Kawsay}

Habermas (2001) proposes an interaction between two main concepts: the notion of system, and that of lifeworld. According to our previous consideration, Sumaq Kawsay relates, in this sense, to what Habermas designs as the life-world. The study of society as a complex system had led previously to emphasizing systems and underestimating the role of social subjects (life-world), who nurture life in all its forms. The German intellectual states that we may not be able to understand the essence of life-world, if we do not consider social systems that configure it; and that we may not be able to comprehend social systems, if we do not think about how they emerge based upon social subjects' actions. In opposition to the system deliberated rationality, lifeworld communicative rationality is proposed. The thesis of rationalities selectivity states that system prevails, changing the daily life-world, but does not destroy it.

Social Subjects' actions are differentiated according to their orientation: 1) Those oriented to success, are instrumental (efficiency related) or strategic (considering an adversary); 2) Those oriented to mutual understanding (coordination of a subject's actions with other subject(s)' actions, by means of a communicative process that leads to consent), the space where Sumaq Kawsay takes place. In order to approach the communicative process, Habermas uses a philosophy of language: on one hand there is the language of perlocution (success oriented), which is a calculated speech, a strategic language that controls concepts and terms; on the other hand, there is the language of elocution (communication oriented). The difference is clearly expressed by the author himself:

Communicative action is distinguished of interactions of the strategic kind, in that every participant, without reticence, search illocutionary goals, with the purpose of agreement reaching, that serves as a foundation for a concerted coordination of the individual action plans. (HABERMAS, 2001)

How is the listener persuaded to act accordingly to what is suggested by the speaker? In strategic language, the speaker has a sanction power in case the listener does not accept his propositions (power pretension). In communicative language, by the contrary, the speaker must illocute argumentatively, in order to reach a rationally motivated understanding (validity pretension). Validity pretension refers to a speaker's intensions or actions during his dialogical relationship with his interlocutor: a) truthfulness, proposition and facts adequacy; moral rectitude, adjustment of the statement to a normative context prevailing in a society; and c) veracity, coherence between a speaker's speech and his intension (SERRANO, 1994).

\section{Deliberative citizen engagement and social management}

Based upon the communicative action approach, Tenório proposes his category of deliberative citizenship, a notion that is located in-between society and state, work and capital, social management and strategic management. Social management is understood as "a dialogic management process, in which the decision power is shared among the participants of an action" (TENÓRIO, 2006). This dialogic process may be present in midst of the state (first sector), in the market (second sector), or in para-economic organizations that constitute the so called third sector.

Republican responsibility is one of the main points introduced by social management, contesting predominant organizational theories that have homologated individual interests as public interest. In the predominant view, citizens are but an aggregation of interests; therefore, they don't participate actively in public action deliberations. A republican vision of development assumes that a vigorous citizenry is not only compatible with an effective public administration, but it is, in fact, essential to effective government (KALU, 2003). 
Deliberative citizenry means that the legitimacy of decisions must come from a discussion processes, oriented by principles of inclusion, pluralism, participation equality, autonomy, and the public good (TENÓRIO, 2006).

The discriminating key between the predominant Western model of development and Sumaq Kawsay is deliberative citizenry. A continuum may be traced between liberalism and republicanism in the public administration sphere; and a continuum between fordism and post-fordism in private administration. A continuum must be understood as a category that denotes a dialectic unity between continuity and discontinuity; a variety of organizations are possible across the continuum.

For instance, fordist organizations are currently the overwhelming majority, with characteristics of mass production, hierarchy, elitism, organization technologies oriented to maximize productivity, instrumental reason, mono-logic action. Even though some flexibility may be found in contemporary organizations, due to scientific and technologic developments, they should be categorized as post-fordist organizations, only with deliberative citizenry praxis, both for public and private organizations.

Sumaq Kawsay needs a deep social elucidation; that is: the process of clarifying the fundamental structure and assumptions of predominant social thought, through a methodology of selection of the ideas that area relevant and pertinent to our Latin American context. Based upon the elucidated social and development essential cores, in synthesis with Latin American scholar and ancestral knowledge, and its cultural praxis, new social and development models and theories may be constructed. The methodological approach is oriented to harmonize individual self-realization, social justice, solidarity, liberty, and sustainability. Balancing human rights and market interests does not assume a single or a better model, many amalgams are possible, many development types may be imagined, respecting and valuing diversity.

\section{Conclusion: Sumaq Kawsay: just a notion or a just nation opportunity?}

Although Sumaq Kawsay originated as a cultural notion from Andean civil society, latterly displaced to academic and political discussions; it seems that, in actual practice, civil society has been ignored by the very same groups that use its cultural discourse in their public policies. In Andean countries, Ecuador in particular, the centrality of civil society that the Sumaq Kawsay principle supports, has been replaced by a strong state concept, which justifies every political action beneath its actual social impact. The power of the state is not only constraining the freedom of the market - the place where human beings share the fruits of their labor, according to Plato - but it is strangulating civil society participation. As we stated before, without deliberative citizenship there is no new development model. Furthermore, actual public policy in Ecuador upholds a vision of development still based on extractive industries, energy and water intensive usage and rural development that contrast with those alternative conceptions of nurturance and solidarity of Sumaq Kawsay.

What is happening with the Yasuni Natural Park initiative is a negative example of actual policies and the principles of the Ecuadorian Constitution. The initiative to keep the oil underground needed a trust-fund as a tool to, amongst other things: guarantee the use of the money according to environmental principles; guarantee that future governments don't exploit these fields; and keep the proposal outside the carbon trade mechanisms. Now the Ecuadorian government is threatening to begin the oil exploitation of the ITT block in June 2010, despite of violating Constitutional principles, among them: the prohibition of oil related activities in protected areas; the protection of indigenous peoples in voluntary isolation; and the obligation to promote measures to face climate change.

It still remains to be seen whether Sumaq Kawsay actually contributes to the social construction of a new and just nation or the Quechua symbolic way of living together stays as just a notion. In conclusion, the question is: May Sumaq Kawsay be really a new development mo-del that allows a new order based on increased and empowered social participation - deliberative citizenship - that would lead actions both from the state and markets and nurtures life in all its forms? 


\section{References}

ADORNO, T.; HORKHEIMER, M. Dialéctica de la llustración. Fragmentos filosóficos. Madrid: Trotta, 1998.

ALBÓ, X. Suma Qamaña - el buen convivir. Revista Obets: Revista de Ciencias Sociales, n.4, p.25-40, 2009.

BOEIRA, S. L. Ecología política: Guerreiro Ramos e Frit Jof Capra. Ambiente \& Sociedade, ano V, n.10, p.1-21, 2002.

CANDLER, G. G. Particularism versus universalism in the Brazilian public administration literature. Public Administration Review, v.62, n.3, p.298-306, 2002.

CARREÑO, P. El quechua y la modernidad: elementos para crear un vocabulario actual. Lima, Mimeografado, 2006.

CHIROQUE, H.; MUTUBERRÍA, V. Procesos de construcción de otras alternativas: desarrollo y planteamiento de la economía social comunitria en América Latina. Revista de economia pùblica, social y cooperativa, n.66, p.147-163, 2009.

COOPER, T. L. Big questions in administrative ethics: a need for focused, collaborative effort. Public Administration Review, v.64, n.4, p.395-407, 2004.

FELDMAN, M et al. Making sense of stories: a rhetorical approach to narrative analysis. Journal of Public Administration Research and Theory, v.14, n.2, p.147-170, 2004.

FREIRE, P. Pedagogía del oprimido. Buenos Aires: Siglo Veintiuno Editores, 2002.

GIBSON, K.The Quechua. Faces, places, and cultures. p.36-38, 2005.

GUERREIRO RAMOS, A. Modelos de homem e teoria administrativa. Public Administration Review, v.32, n.3, p.241246, 1972.

A nova ciência das organizações: uma reconceituação da riqueza das nações. Rio de Janeiro: Editora da Fundação Getulio Vargas, 1981.

. A redução sociológica em Heidemann, F. In: MODELOS de homem e teoria administrativa. Caderno de Ciências Sociais Aplicadas, PUC-PR, n.3, 2001.

HABERMAS, J. Conocimiento e interés. Madrid: Taurus, 1990.

Teoría de la acción comunicativa, II. Crítica de la razón funcionalista. Bogotá: Taurus Humanidades, 2001.

HARRIS, M. History and significance of the emic/etic distinction. Annual Review of Anthropology, v.5, p.329-359,1976.

HORKHEIMER, M. Crítica de la razón instrumental. Madrid: Trotta, 2002.

Eclipse of reason. New York: Continuum, 2004.

ISHIZAWA, J.; GRILLO, E. Loving the world as it is: Western abstraction and Andean nurturance. ReVision 24. 4, p.21-30, 2002

KALU, K. Of citizenship, virtue, and the administrative imperative: deconstructing Aristotelian civic republicanism. Public Administration Review, v.63, n.4, p.418-427, 2003.

KESSEL, J. Economía bidimensional andina. Revista de Ciencias Sociales, Chile, v.17, p.86-106, 2006.

MALLON, R. A field guide to social construction. Philosophy Compass, v.2, n.1, p.93-108, 2007.

MORGAN, G. Imágenes de la organización. México: Ediciones Alfaomega, 1991.

MORRISSEY, L. F. The rise of ethnic politics: indigenous movements in the Andean region. Development, v.52, n.4, p.495-499, 2009.

OSSIO, J. Cosmologies. International Social Science Journal, v.49, n.4, p.549-558, 1997.

SALGADO, F. Organizational theories from a Latin American perspective. In: Latin American and European meeting on organizational studies, 2, Rio de Janeiro, 2008.

SERRANO, E. Legitimación y racionalización. Weber y Habermas: la dimensión normativa de un orden secularizado. Barcelona: Anthropos, 1994.

SKAR, S. L. Appropriating pawns: Andean dominance and the manipulations of things. Journal of the Royal Anthropologicial Institute, v.1. n.4, p.787-797, 1995. 
TENÓRIO, F. G. Teorías organizacionales bajo el orden y el progreso, o cuando los vivos son gobernados por los muertos. FGV - EBAPE, 2006.

VENTRISS, C.; CANDELL, G. G. Alberto Guerreiro Ramos, 20 years later: a new science still unrealized in an era of public cynicism and theoretical ambivalence. Public Administration Review, v.65, n.3, p.347-359, 2005.

WEBER, M. Economía y sociedad. México: Fondo de Cultura Económica, 1999.

. La ética protestante y el espíritu del capitalismo. México: Fondo de Cultura Económica, 2004. 